УДК 347.51

DOI https:/ / doi.org/10.32837/yuv.v0i3.1952

\author{
Д. Кравчук, \\ аспірант \\ Київського національного університету імені Тараса Шевченка
}

\title{
УМОВИ ЦИВІЛЬНО-ПРАВОВОї ВІДПОВІДАЛЬНОСТІ ДЕРЖАВИ
}

Постановка проблеми. Гострою науково-прикладною темою сучасного цивільного права є дискусія щодо цивільно-правової відповідальності держави. Особливого значення вона набуває у період розповсюдження терористичної небезпеки, ведення «гібридних» воєн та обмежень, викликаних поширенням небезпечних захворювань. Важливим елементом реалізації державних гарантій із відшкодування завданої шкоди $€$ визначення умов відповідальності. На відміну від підстав як фактів, передбачених законом, що породжують відповідне цивільно-правове явище (зобов'язання з відшкодування завданої шкоди), умовами визнаються ознаки, якими ці підстави характеризуються і які випливають із закону.

У науці цивільного права зазначені умови поділяються на загальні та спеціальні. До загальних умов відшкодування шкоди належать наявність завданої шкоди, протиправність поведінки суб'єкта відповідальності, наявність причинного зв'язку між ними та вина завдавача шкоди [1, с. 728].

Спеціальні умови є додатковими до загальних, наприклад, особливий суб'єктний склад відшкодування шкоди, заподіяної актами органів влади. При цьому під складом цивільного правопорушення традиційно розуміють сукупність загальних, типових умов, наявність яких необхідна для покладення відповідальності на порушника цивільних прав і обов'язків і які в різних поєднаннях втілюються у будь-якому цивільному правопорушенні.
Аналіз останніх досліджень i публікацій. Питання цивільно-правової відповідальності держави були в центрі наукових досліджень таких науковців, як Т.В. Боднар, Ю.Л. Бошицький, С.Н. Братусь, В.В. Вітрянський, Л.В. Винар, Т.С. Ківалова, В.М. Коссак, О.О. Кот, О.В. Кохановська, Н.С. Кузнєцова, Р.А. Майданик, О.О. Отраднова, O.O. Первомайський, I.В. СпасибоФатеєва, М.М. Хоменка та інші.

Незважаючи на чималу кількість досліджень, присвячених умовам та підставам цивільно-правової відповідальності держави за заподіяну шкоду, окремі проблемні питання характеристики умов цивільно-правової відповідальності держави за заподіяну шкоду залишаються не вирішеними та призводять до формування неоднозначної правозастосовної практики. Насамперед це зумовлено дискусійністю та неоднозначним розумінням у теорії поняття «цивільно-правової відповідальності».

Мета статті полягає в аналізі змісту теоретичної конструкції умов цивільно-правової відповідальності держави за заподіяну шкоду, яка може бути використана у доктринальному та практичному аспектах реалізації цивільно-правової відповідальності держави.

Виклад основного матеріалу. Умовою цивільно-правової відповідальності держави є наявність складу правопорушення в діях суб'єктів права. В.В. Вітрянський вказував, що обов'язковими загальними вимогами, дотримання яких необхідне для 
застосування цивільно-правової відповідальності, $є$ протиправність порушення суб'єктивних цивільних прав, наявність збитків (шкоди), причинного зв'язку між порушенням суб'єктивних цивільних прав і збитками (шкодою), вина порушника [2, с. 569].

У деліктних правовідносинах протиправність в об'єктивному розумінні, тобто порушення норми права, не $є$ обов'язковою умовою покладення на особу відповідальності. Само по собі порушення об'єктивних норм не матиме значення для цивільного права, якщо при цьому не будуть порушені якісь суб'єктивні особисті немайнові або майнові права особи. I навпаки, якщо особі заподіяна шкода, заподіювач буде зобов'язаний ii відшкодувати, навіть якщо він не порушував якихось формальних положень законодавства [3, с. 73].

Протиправність у деліктних правовідносинах слід розуміти широко. Протиправним є будь-яке діяння, яке спричинило порушення суб’єктивних прав особи, заподіяння шкоди іï майновим або особистим немайновим інтересам, якщо особа не була уповноважена на заподіяння шкоди. Звільнення особи від відповідальності за шкоду, заподіяну протиправними діями, можливе тільки у випадках, прямо встановлених законом.

Наявність такої умови цивільноправової відповідальності, як причинний зв'язок між порушенням зобов'язання і настанням негативних наслідків, визначена необхідністю встановлення того факту, що саме протиправна поведінка боржника, на якого покладається цивільно-правова відповідальність, є тією безпосередньою причиною, що завдала збитків і спричинила моральну шкоду кредиторові.

У практичній площині питання про наявність або відсутність причинного зв'язку між протиправною поведінкою особи, яка порушила зобов'язання, і настанням негативних наслідків у кредитора - це питання факту, яке має бути вирішене судом шляхом ретельної оцінки всіх фактичних обставин справи [4, с. 86].

Причинний зв'язок між протиправним діянням заподіювача шкоди та шкодою, заподіяною потерпілим, є обов'язковою умовою настання деліктної відповідальності. Визначення причинного зв'язку як умови деліктної відповідальності $€$ необхідним і для забезпечення інтересів потерпілого, і для реалізації принципу справедливості при покладенні на особу обов'язку відшкодувати заподіяну шкоду [3, с. 74].

У літературі зустрічається розширене тлумачення поняття «вини», визначеного ст. 614 ЦК України, відповідно до якого «під всіма заходами щодо належного виконання зобов'язання треба розуміти ті дії, які вчинила б у такому випадку нормальна особа, тобто середня розумна людина, яка передбачає негативні наслідки своїх дій і здатна корегувати їх з метою запобігання заподіянню шкоди» [5, с. 476]. Завдяки такому розумінню визначення вини, що випливає з положення ст. 614 ЦК України, можна застосувати й до деліктних зобов'язань.

Якщо буквально тлумачити ст. 614 ЦК України, можна дійти висновку, що без застережень таке визначення вини може бути застосоване тільки до договірних зобов'язань, оскільки тільки у договірних відносинах зобов'язання існує до моменту притягнення особи до відповідальності, а тому можна говорити про його неналежне виконання.

Що стосується зобов'язань із заподіяння недоговірної шкоди, що регулюються главою 82 ЦК України, то тут, як слушно зазначає О.О. Отраднова, беззастережно застосувати визначення вини відповідно до ст. 614 ЦК України не можна [3, с. 75]. До моменту заподіяння шкоди заподіювач шкоди не перебуває у відносинах, зобов'язальних правовідносинах із потерпілим, він має лише абсолютні обов'язки, 
що кореспондують абсолютним майновим або особистим немайновим правам потерпілого.

За загальним правилом відповідальність за порушення зобов'язання настає за наявності вини особи, яка порушила зобов'язання (з умислу чи необмеженості), якщо інше не передбачено законом чи договором (ст. 614 ЦК України). В окремих випадках законодавець передбачає відповідальність незалежно від того, чи має місце вина відповідальної особи. Наявність у цивільному праві випадків, коли відповідальність настає без вини, В.П. Грибанов пов'язував із відмінністю в основних функціях юридичної відповідальності в кримінальному та цивільному праві. Головна функція цивільно-правової відповідальності - це відшкодування заподіяної шкоди або збитків [6, с. 342].

Саме поняття «відповідальність без вини» і відмежування відповідальності «без вини» від відповідальності «за вину» залежить насамперед від розуміння поняття «вина» у цивільному праві. У цивілістичній доктрині відповідальність без вини і відповідальність за вину в різні історичні часи трактувалася по-різному. На відміну від кримінального права, у цивільному праві ми можемо виявити низку інститутів як договірного, так i недоговірного права, коли настає так звана відповідальність і без вини.

$\mathrm{y}$ деліктних зобов'язаннях прикладами такої відповідальності $€$ відповідальність держави за відшкодування шкоди, завданої незаконними рішеннями, діями чи бездіяльністю органу, який здійснює оперативно-розшукову діяльність, досудове розслідування, прокуратури або суду (ст. 1176 ЦК України). Скажімо, особа була засуджена внаслідок завідомо неправдивих свідчень або завідомо неправдивого висновку експерта, проте, незважаючи на відсутність безпосередньої вини з боку працівників прокуратури та суду, відшкодовувати заподіяні збитки буде держава; відшкодування (компенсація) шкоди фізичній особі, яка потерпіла від кримінального правопорушення (ст. 1177 ЦК України); відшкодування шкоди, завданої каліцтвом, іншої шкоди здоров'ю або смерті внаслідок злочину (ст. 1207 ЦК України).

У сучасній доктрині цивільного права такі правовідносини традиційно називають відповідальністю без вини, але ставлення до них неоднозначні. Так, Д.В. Боброва, розглядаючи питання про відповідальність незалежно від вини в контексті відповідальності володільця джерела підвищеної небезпеки, вважала, що існування такої відповідальності «в сучасних умовах науково-технічного прогресу, ускладнення усіх сторін життя суспільства - важливий правовий інструмент забезпечення соціальної справедливості» [7, с. 534-535]. I.C. Канзафарова зазначає, що «відповідальність без вини суперечить принципу справедливості» і пропонує розглядати такі випадки не як відповідальність, а як «іiі модель - квазівідповідальність» [8, с. 92].

Більшість авторів вважають, що правовідносини юридичної відповідальності виникають 3 моменту вчинення правопорушення [9, с. 145-159]. На думку Н.С. Кузнєцової, порушення права суб'єкта цивільних відносин викликає необхідність відновлення порушеного права, в тому числі і шляхом застосування цивільно-правової відповідальності. Підставою такої відповідальності $€$ саме порушення суб'єктивного цивільного права [10, с. 345].

У літературі висловлювалися i пропозиціі щодо підстав звільнення від відповідальності без вини. P.A. Майданик пропонує як умову звільнення від безвинної відповідальності розглядати виправданий (припустимий) ризик, під яким розуміються діi заподіювача шкоди, спрямовані на недопущення шкідливого результату (шкоди), відповідно до стандартів поведінки (діяльності). Відповідно шкода, завдана лікарем, пожежником, 
військовослужбовцем у ситуації виправданого (правомірного) ризику, якщо при цьому не було перевищення його меж, відшкодуванню не повинна підлягати [11, с. 125].

Відмова від інституту відповідальності без вини у цивільному праві потребує створення певного механізму, який би забезпечив дієвий захист інтересів осіб, яким була заподіяна шкода.

Обов'язок держави компенсувати шкоду незалежно від іï вини був предметом розгляду ЄСПЛ. У рішенні Європейського суду з прав людини від 8 січня 2004 року у справі «Айдер та інші проти Туреччини» [12] суд зазначив, що відповідальність держави носить абсолютний характер і має об'єктивну природу, засновану на теорії соціального ризику (social risk). Таким чином, держава може бути притягнута до відповідальності $з$ метою компенсації шкоди тим, хто постраждав від дій невстановлених осіб або терористів, якщо країна визнає свою нездатність підтримувати громадський порядок і безпеку або захищати життя людей і їхн власність (п. 70). Тому вина не завжди $є$ обов'язковою умовою цивільно-правової відповідальності.

Окремої уваги при дослідженні цивільно-правової відповідальності держави за заподіяну шкоду потребують спеціальні делікти, які характеризуються наявністю додаткових умов їх виникнення. Проблеми класифікації таких дій, особливість процедури розгляду справ, неоднозначність і певна суперечливість судової практики зумовлюють наявність певних перешкод для захисту порушених прав суб’єктів цивільних правовідносин. У межах цього дослідження нами буде розглянуто особливості умов відшкодування шкоди, заподіяної актами влади, та відшкодування шкоди, заподіяної органами досудового розслідування, прокуратури та суду.

Так, чинний ЦК України надав розвиток положенню ст. 56 Конституції
України, відповідно до якої кожен має право на відшкодування за рахунок держави чи органів місцевого самоврядування матеріальної та моральної шкоди, заподіяної незаконними рішеннями, діями чи бездіяльністю органів державної влади, органів місцевого самоврядування, їх посадових і службових осіб при здійсненні ними своїх повноважень [13].

Питання відшкодування шкоди, заподіяної актами влади, в ЦК України врегульовані у трьох статтях Глави 82: ст. 1173 «Відшкодування шкоди, завданої органом державної влади, органом влади Автономної Республіки Крим або органом місцевого самоврядування», ст. 1174 «Відшкодування шкоди, завданої посадовою або службовою особою органу державної влади, органу влади Автономної Республіки Крим або органу місцевого самоврядування», ст. 1175 «Відшкодування шкоди, завданої органом державної влади, органом влади Автономної Республіки Крим або органом місцевого самоврядування у сфері нормотворчої діяльності».

У теорії цивільного права норми, які містяться у вказаних вище статтях, прийнято називати правилами про спеціальний делікт - шкоду, заподіяну актами влади. Підставами для виокремлення таких випадків у спеціальний делікт $€$ особливості застосування до нього як загальних умов недоговірної відповідальності, так і спеціальних умов, додатково встановлених законом [3, с. 109].

Основна специфіка спеціального делікту полягає в суб'єктивному складі заподіювачів шкоди. Так, суб'єктами заподіяння шкоди в такому випадку виступають органи державної влади, органи місцевого самоврядування, посадові та службові особи відповідних органів. Відшкодування шкоди, заподіяної актами влади, не залежить від того, хто виступає в ролі потерпілого, - фізична чи юридична особа. Саме цим ЦК України 2003 року істотно відрізняється від ЦК УРСР 1963 року. 
Певними особливостями характеризується і така загальна умова відповідальності, як протиправність актів влади. У ст.ст. 1173-1175 ЦК України йдеться про «незаконні» рішення, дію чи бездіяльність органу державної влади, органу місцевого самоврядування, їх посадових або службових осіб, а також про прийняття зазначеними вище органами «незаконного» нормативно-правового акту, який було скасовано [3, с. 110].

Незаконними є діяння, акти індивідуальної дії або нормативно-правові акти, які суперечать не тільки законам, а й іншим правовим актам. Такі діяння можуть мати різноманітні види та форми. Це можуть бути накази, розпорядження, вказівки або інші владні приписи (причому не має значення, розроблені вони в усній чи в письмовій формі), що підлягають обов'язковому виконанню фізичними та юридичними особами, яким вони адресовані. Загальний порядок визнання недійсними актів індивідуальної дії та нормативно-правових актів органу влади у зв'язку з їх невідповідністю положенням законодавства передбачений ст. 21 ЦК України.

Рішення, дії чи бездіяльність органів влади оскаржуються в процесі адміністративного судочинства за правилами Кодексу адміністративного судочинства України. Висновки щодо вирішення питань про відповідність Конституції України (конституційність) законів України та інших правових актів Верховної Ради Україн, актів Президента України, актів Кабінету Міністрів України, правових актів Верховної Ради Автономної Республіки Крим приймаються Конституційним Судом України (ст. 7 ЗУ «Про Конституційний Суд України») [14].

Поряд із діями, тобто активною поведінкою державних органів, органів місцевого самоврядування, їх посадових і службових осіб, шкода у зазначеній сфері може бути заподіяна i шляхом протиправної бездіяльності, оскільки в області владно- адміністративних відносин вимагається активність, а неприйняття необхідних заходів, передбачених законами чи іншими правовими актами, може призвести до заподіяння шкоди.

Слід зазначити, що переліку незаконних діянь органів державної влади та місцевого самоврядування, які можуть породжувати деліктні зобов'язання, передбачені ст.ст. 1173-1175 ЦК України, законодавство не містить. Отже, ними можуть бути будь-які діяння, акти управління та нормативні акти за умови, що вони прийняті при здійсненні зазначеними вище органами, ї посадовими або службовими особами своїх повноважень.

Якщо шкода заподіюється не в сфері адміністративно-владних відносин, а в сфері господарської або технічної діяльності (наприклад, у результаті ДТП шкода заподіюється громадянину автомобілем голови обласної державної адміністраціі), вона підлягає відшкодуванню не на підставі ст.ст. 1173-1175 ЦК України, а на загальних підставах (у вказаному випадку на підставі ст. 1187 ЦК Украіни) $[3$, с. 111].

В українському деліктному праві, як і в праві більшості країн континентальної Європи, застосовується система генерального делікту, відповідно до якої будь-яке заподіяння шкоди визначається протиправним і тягне за собою обов'язок заподіювача відшкодувати таку шкоду, якщо він не доведе свою уповноваженість на іiі заподіяння. В області, яка розглядається, діє протилежне правило, що будь-який акт влади визнається законним, у тому числі й той, яким заподіяно шкоду. Отже, для відшкодування шкоди необхідно визнати акт влади незаконним. Шкода, заподіяна внаслідок прийняття органом влади незаконного нормативно-правового акта, підлягає відшкодуванню лише тоді, якщо такий нормативно-правовий акт було визнано у відповідному порядку незаконним і скасовано (ст. 1175 ЦК України). 
Специфіка суб'єктивної умови відповідальності полягає в тому, що в ЦК України 2003 року вперше визначено, що шкода, заподіяна органами державної влади, органами місцевого самоврядування при здійсненні ними своїх повноважень або у сфері нормотворчої діяльності, а також шкода, заподіяна посадовими або службовими особами зазначених органів, відшкодовується незалежно від вини цих органів, їх посадових або службових осіб.

Відповідно до ст.ст. 1173-1175 ЦК України шкода, заподіяна органами державної влади, органами місцевого самоврядування, посадовими або службовими особами зазначених органів відшкодовується відповідно державою, органами місцевого самоврядування. Від імені держави, органів місцевого самоврядування здебільшого виступають відповідні фінансові органи, тобто державне казначейство, фінансові управління, районні фінансові відділи тощо. Держава Україна, органи місцевого самоврядування мають право зворотної вимоги (регресу) до винної особи у розмірі виплаченого відшкодування, якщо інший розмір не встановлений законом (ч. 1 ст. 1191 ЦК України) [3, c. 112-113].

Також при дослідженні цивільноправової відповідальності держави за заподіяну шкоду детального розгляду потребує відшкодування шкоди, заподіяної органами досудового розслідування, прокуратури та суду. У зв'язку з особливостями суб'єктного складу та переліку протиправних діянь відшкодування шкоди, заподіяної правоохоронними та судовими органами, здійснюється за правилами спеціального делікту. У дореволюційний період такий делікт обмежувався лише відповідальністю «чинів судового відомства», які були зобов'язані відшкодувати шкоду, заподіяну внаслідок ї «неправильних та упереджених дій» [15, с. 472-473]. Проте відповідальність суддів також будувалася виключно на особливому порядку, встановленому процесуальними законами. Спеціальних норм матеріального цивільного права в цій сфері не існувало.

Натепер відшкодування шкоди, заподіяної особі незаконним рішенням, діями чи бездіяльністю органу досудового розслідування, прокуратури або суду, крім спеціального законодавства регулюються положеннями ст. 1176 ЦК України. Порівняно з умовами генерального делікту, цей спеціальний делікт має низку специфічних ознак. Насамперед особливим $€$ суб'єктний склад заподіювачів шкоди. Відповідно до положень ст. 1176 ЦК України суб'єктами заподіяння шкоди вважаються такі органи.

Слід наголосити, що потерпілою від незаконних дій органів досудового розслідування, прокуратури та суду в галузі кримінального процесу та притягнення особи до адміністративної відповідальності за правилами ст. 1176 ЦК України може бути виключно фізична особа. Шкода, заподіяна незаконними діями правоохоронних і судових органів юридичній особі, підлягає відшкодуванню за нормами ст.ст. 1173-1175 ЦК України. Заподіяна потерпілому шкода відшкодовується за рахунок коштів Державного бюджету в повному обсязі незалежно від вини службових осіб правоохоронних і судових органів [4, c. 118].

Висновки. Умовами цивільноправової відповідальності держави $є$ кожен із класичних елементів (підстав) відповідальності суб'єкта цивільно-правових відносин. Водночас специфіка суб'єктивної умови відповідальності полягає в тому, що в ЦК України 2003 року вперше визначено, що шкода, заподіяна органами державної влади, органами місцевого самоврядування при здійсненні ними своїх повноважень або у сфері нормотворчої діяльності, а також шкода, заподіяна посадовими або службовими особами 
зазначених органів, відшкодовується незалежно від вини цих органів, їх посадових або службових осіб. Стосовно визначення об'єктивної сторони складу правопорушення наголосимо, що ними можуть бути будь-які діяння, акти управління та нормативні акти за умови, що вони прийняті при здійсненні зазначеними вище органами, їх посадовими або службовими особами своїх повноважень.

Окремої уваги при дослідженні цивільно-правової відповідальності держави за заподіяну шкоду потребують спеціальні делікти, які характеризуються наявністю додаткових умов їх виникнення. Проблеми класифікації таких дій, особливість процедури розгляду справ, неоднозначність і певна суперечливість судової практики зумовлюють наявність певних перешкод для захисту порушених прав суб’єктів цивільних правовідносин.

Цивільно-правова відповідальність держави - це безумовний обов'язок держави в особі відповідальних органів державної влади або юридичних осіб публічного права здійснити справедливе відшкодування (компенсувати) заподіяну потерпілій особі матеріальну та (або) моральну шкоду, викликану організаційно-управлінськими, військово-політичними, організаційно-правовими рішеннями, діями та заходами органів державної влади, їх посадових осіб, службовцями, «невстановленими особами», а також шкоду, спричинену в результаті вчинення терористичних актів, спрямованих на порушення громадської безпеки, залякування населення, провокації воєнного конфлікту, міжнародного ускладнення, або 3 метою впливу на прийняття рішень чи вчинення або не вчинення дій органами державної влади чи органами місцевого самоврядування, службовими особами цих органів.

Стаття присвячена питанням умов изиільно-правової відповідальності держави. Умовами цчивільно-правової відповідальності держави є класичні елеменmu відповідальності суб'єкта циивільно-правових відносин з урахуванням певної специиіки. Так, специфіка суб'єктивної умови відповідальності полягає в тому, що в ЦК Украйни вперше визначено, що шкода, заподіяна органами державної влади, органами місиевого самоврядування при здійсненні ними своїх повноважень або у сфері нормотворчої діяльності, а також шкода, заподіяна посадовими або службовими особами зазначених органів, відшкодовується незалежно від вини иих органів, їх посадових або службових осіб.

Наголошено, шо до складу об'єктивної сторони складу правопорушення можна віднести прийняті акти управління або нормативні акти органів влади за умови, що вони прийняті при здійсненні зазначеними вище органами, ї посадовими або службовими особами своїх повноважень.

Окремої уваги при дослідженні изивільно-правової відповідальності держави за заподіяну шкоду потребують спеціальні делікти, які характеризуються наявністю додаткових умов їх виникнення. Проблеми класифікації таких дій, особливість процедури розгляду справ, неоднозначність і певна суперечливість судової практики зумовлюють наявність певних перешкод для захисту порушених прав суб'єктів ицивільних правовідносин.

Зазначено, що иивільно-правова відповідальність держави - це безумовний обов'язок держави в особі відповідальних органів державної влади або юридичних осіб публічного права здійснити справедливе відикодування (компенсувати) заподіяну потерпілій особі матеріальну та (або) моральну шкоду, викликану організаційно-управлінськими, військово-політичними, організаційно-правовими рішеннями, діями та заходами органів 
державної влади, їх посадових осіб, службовиями, «невстановленими особами», а також шкоду, спричинену в результаті вчинення терористичних актів, спрямованих на порушення громадської безпеки, залякування населення, провокаціі воєнного конфлікту, міжнародного ускладнення, або з метою впливу на прийняття рішень чи вчинення або не вчинення дій органами державної влади чи органами місцевого самоврядування, службовими особами ичих органів.

Ключові слова: відповідальність, держава, умови відповідальності, майнова шкода, склад правопорушення.

Kravchuk D. Circumstances of civil law responsibility of the state

The paper is dedicated to issues on circumstances of civillaw responsibility of the state. Circumstances of civil law responsibility of the state consist of classic elements of responsibility of the subject of civil law relations including certain specifics. Thus, Civil Code of Ukraine determines firstly that the damage which is caused by public authorities, local governments in the exercise of their powers or in the field of rule-making activities and damage which is caused by officials of these authorities and governments is reimbursed regardless of the fault of these authorities or their officials; and this statement is the essence of the specifics of subjective circumstance of responsibility.

There is stressed, that into composition of objective side of composition of offense could be included public authorities' acts of management or regulations as well as they are adopted in the exercise of the above-mentioned authorities and their officials of their powers.

There is emphasized, that special torts that are characterized by additional conditions of their appearing demand especial attention in the process of researching of civil and law responsibility of the state for the caused damage.

Problems of classification of such activities, peculiarities of the proceedings procedure, ambiguity and a certain contradiction of judicial practice cause certain obstacles to the protection of violated rights of subjects of Civil Law. There is indicated, that the civil law responsibility of the state is the unconditional obligation of the state represented by responsible public authorities or legal entities under Public Law to make fair compensation (to compensate) for material and (or) moral damage caused to the victim that is caused by organizational and administrative, military-political, organizational and legal decisions, actions and measures of public authorities, their officials, servants, unknown persons, and also damage that is a result of terroristic acts are aimed to violation of public safety, intimidation of the population, provocations of military conflict, international complications, or to impact on making decisions or committing or failing to act by state authorities or local self-government authorities, officials of these authorities.

Key words: responsibility, state, circumstances of responsibility, property damage, composition of the offense.

\section{Література}

1. Цивільне право : підручник: у 2-х $\mathrm{m}$. за ред. В.I. Борисової, I.В. Спасибо-Фатєєвої, В.Л. Яроцького. Х. : Право, 2011. T. 2. $816 \mathrm{C}$.

2. Брагинский М. И., Витрянский В.В. Договорное право. Общие положення. 3 изд., cmepeomun. M. : Cmamym, 2001. $842 \mathrm{c}$.

3. Отраднова О.О. Недоговірні зобов'язання в иивільному праві України : навч. посібн. К. : Юрінком Інтер, 2009. $240 \mathrm{c}$.

4. Сібілов М. Піәстава та умови цивільно-правової відповідальності за порушення договірних зобов'язань за чинним Цивільним кодексом України. 


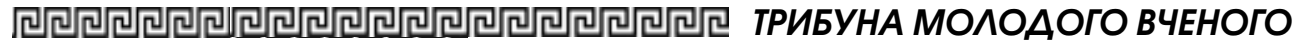

Вісник Академії правових наук України. № 2(37). С. 80-88.

5. Цивільний кодекс України: науково-практичний коментар: у 2 ч. за заг. ред. Я.М. Шевченко. К. : Концерн «Видавничий Дім «Ін Юре». Ч. 2. 896 с.

6. Грибанов В.П. Осуществление и защита гражданских прав. М. : Статут, 2001. $411 \mathrm{C}$.

7. Цивільне право України : підручник: у 2-х кн. за ред. О.В. Дзери, Н.С. Кузнєиової. К. : Юрінком Інтер, 2002. 722 с.

8. Канзафарова I.С. До проблеми циивільно-правової відповідальності без вини. Вісник Хмельницького університету права. 2003. № 3. С. 89-95.

9. Канзафарова І.С. Теорія цивільноправової відповідальності : монографія. Oдеса, 2006. 264 c.

10. Інститут цивільно-правової відповідальності у иивілістичній доктрині України. Правова доктрина України: у 5 m. Х. : Право, 2013, Т. 3 Доктрина приватного права. за заг. ред. Н.С. Кузнєцової. C. 330-348.
11. Майданик Р.А. Цивільно-правова відповідальність. Юридична відповідальність: проблеми виключення та звільнення. Колектив авторів, відп. ред. Ю.В. Баулін. Донещьк : ПП «ВД «Кальміус», 2013. С. 86-147.

12. Справа «Айдер та інші проти Туреччини» (заява № 23656/94) : Рішення Європейського суду з прав людини від 08.01.2004. URL: http: / / eurocourt.in.ua/ Article.asp?AIdx=607 (дата звернення: 05.02.2020)

13. Конституиія України : Закон України від 28.06.1996 № 254к/96-BP. URL: https: / / zakon.rada.gov.ua/laws / show $/ 254 \% D 0 \% B A / 96-\% D 0 \%$ B2\% D1\% 80 (dama звернення: 05.02.2020).

14. Про Конституційний Суд України : Закон України від 13.07.2017 № 2136-VIII. URL: https: / / zakon.rada.gov.ua/laws / show/2136-19 (дата звернення: 05.02.2020).

15. Синайский В.И. Русское гражданское право. М. : Cmamym, 2002, C. 472-473. 